\title{
A Stochastic Dynamic Methodology (SDM) to the modelling of trophic interactions, with a focus on estuarine eutrophication scenarios
}

\author{
Pedro Silva-Santos ${ }^{\mathrm{a}, *}$, Miguel Ângelo Pardal ${ }^{\mathrm{b}}$, Ricardo Jorge Lopes ${ }^{\mathrm{c}}$, \\ Tiago Múrias ${ }^{\mathrm{c}}$, João Alexandre Cabral ${ }^{\mathrm{a}}$ \\ ${ }^{a}$ Laboratory of Applied Ecology, CETAV-Department of Biological and Environmental Engineering, \\ University of Trás-os-Montes e Alto Douro, 5000-911 Vila Real, Portugal \\ ${ }^{\mathrm{b}}$ IMAR (Institute of Marine Research), Department of Zoology, University of Coimbra, 3004-517 Coimbra, Portugal \\ ${ }^{c}$ CIBIO - Research Center in Biodiversity and Genetic Resources, University of Porto, Campus Agrário de Vairão, \\ Rua Padre Armando Quintas - Crasto 4485-661 Vairão, Portugal
}

Received 6 January 2005; received in revised form 5 May 2005; accepted 24 May 2005

\begin{abstract}
In the face of global change, declines in environmental quality are of increasing concern, especially in shallow coastal areas, densely populated and commonly affected by nutrient enrichment. The warm temperate Mondego estuary (Western Portugal), in common with many other shallow estuarine areas, is exhibiting increased macroalgal growth due to nutrient enrichment. The increase of macroalgal biomass and possible shift of other primary producers resulting from eutrophication, may have profound effects on estuarine trophic chain. The present paper examined the performance of a holistic Stochastic Dynamic Methodology (SDM) in predicting the tendencies of three representative trophic levels as a response to the increase of nutrient concentrations. Therefore, the proposed methodology has been developed by focusing on the interactions between conceptually isolated key-components, such as primary producers (macroalgae and seagrass), some relevant benthic macroinvertebrates, wading birds and changes in local physicochemical conditions. The dynamic model developed was preceded by a conventional multivariate statistical procedure (stepwise multiple regression analysis) performed to discriminate the significant relationships between prevailing biological and environmental variables. Since this statistical analysis is static, the dataset recorded from the field included true gradients of habitat changes. The data used in the model construction was sampled between January 1993 and September 1995 in three areas of the estuary mudflats for benthic macroinvertebrates, macroalgae, environmental and physicochemical factors and from October 1993 to October 1994 for wading birds. The model validation was based on independent data collected in two different periods, from January 1996 to January 1997 and from February 1999 to April 2000 for all the variables selected. Overall, the simulation results are encouraging since they seem to demonstrate the model reliability in capturing the trophic dynamics of the studied estuary by predicting the behavioural pattern for the most part of the components selected under a very complex and variable environmental scenario.
\end{abstract}

(C) 2005 Published by Elsevier Ltd.

Keywords: Stochastic dynamic modelling; Ecological integrity; Eutrophication; Mondego estuary; Trophic interactions

\footnotetext{
* Corresponding author. Tel.: +351 259350 239; fax: +351 259350266 .

E-mail address: pedross@utad.pt (P. Silva-Santos).
} 


\section{Introduction}

Eutrophication of coastal systems is increasing worldwide in response to increased nutrient loading from urban areas and cultivated land areas (Kinney and Roman, 1998; Flindt et al., 1999; Cloern, 2001). Nutrient enrichment has stimulated opportunistic algal growth leading to the occurrence of macroalgal blooms and extinction of seagrass in shallow areas (Kinney and Roman, 1998; Flindt et al., 1999; Pardal et al., 2000, 2004; Kamer et al., 2001). The green macroalgae often responsible for these blooms, such as Enteromorpha spp., have high surface area:volume ratios that allow them to rapidly take up nutrients from the water column (Rosenberg and Ramus, 1984). Following the bloom, decomposing algae contribute significant quantities of dead organic material to the sediments. This may result in the development of anoxic conditions and high hydrogen sulphide concentrations, which are lethal to rooted macrophytes (Pardal, 1998; Terrados et al., 1999).

In the Mondego estuary, blooms of green macroalgae, primarily Enteromorpha spp., have been observed from early spring to late summer (Pardal et al., 2000, 2004; Cardoso et al., 2002, 2004a), as a clear sign of nutrient enrichment. As a result of competition with algae, the extension of the seagrass meadows (mainly Zostera noltii) has been reduced, which caused a shift in primary producers. Through time, this process gave origin to a new trophic structure (Dolbeth et al., 2003; Cardoso et al., 2004a). The energy flow at the secondary and tertiary levels will be affected, which may finally affect the populations from the upper trophic level organisms, in this case dominated by wading birds (Cabral et al., 1999; Lopes et al., 2002). The Mondego estuary, along with other Portuguese estuaries (Tagus, Sado and Minho) and rias (Aveiro and Formosa), supports a large number of waders, due to the existence of suitable supratidal habitats and an important intertidal benthic macroinvertebrate community (Marques et al., 1993).

One of the great challenges in ecological integrity studies is to predict how anthropogenic environmental changes will affect the abundance of species or communities in disturbed ecosystems (Kareiva et al., 1993; Andreasen et al., 2001). Static models with fixed parameters are, in general, unable to estimate the structural changes when the habitat conditions are substantially changing (Jørgensen and Bernardi, 1997). Therefore, ecological integrity studies have been improved by creating dynamic and structural dynamic models that simultaneously attempt to capture the structure and the composition in those systems (Jørgensen, 1994; Chaloupka, 2002). The application of ecological modelling is able to synthesize the pieces of ecological knowledge, emphasizing the need for a holistic view of a certain environmental problem, such as the medium-longterm directional disturbances in stressed ecosystems (Brosse et al., 2001; Cabral et al., 2001; Voinov et al., 2001; Jørgensen, 2001; Santos and Cabral, 2003; Cabecinha et al., 2004). Nevertheless, environmental health assessment and community studies usually result in complex biological data sets. In order to find ecological relevant holistic patterns and tendencies from such sets of data it is necessary to synthesize all the information to a more simplified form (Pardal et al., 2004). In this scope, an expeditious Stochastic Dynamic Methodology (SDM) has recently been developed and successfully applied in relatively ecological stable systems, such as mountain freshwater running waters (Cabecinha et al., 2004) and mediterranean agroecosystems (Santos and Cabral, 2003).

Since many studies refer that changes in primary producers due to eutrophication affect the production of the other trophic levels (Flindt et al., 1999; Pardal et al., 2000, 2002; Beukema et al., 2002; Cardoso et al., 2002), the main objective of the present paper was to demonstrate the applicability of a holistic SDM approach in the scope of the trophic dynamics resulting from changing complex and variable environmental scenarios. Therefore, the goal of this study is to construct a simple demonstrative SDM model by focusing the interactions between conceptually isolated key-components in the Mondego estuary, namely between three selected trophic levels (primary producers, benthic macroinvertebrates and wading birds) and physicochemical conditions. A previous overview of this problematic in Mondego estuary, suggested that these trophic levels have several characteristics that justified their relevance as ecological indicators: (1) they usually occur in high densities/biomass in the studied areas, (2) they provide cheap and easy measurements if standard methodol- 
ogies are applied, (3) they are sensitive to environmental changes, (4) several species were studied intensively with regard to their natural variation, (5) for many species, demography, behaviour, distribution and phenology are connected with seasonal and spatial changes through gradients of estuarine eutrophication and (6) they have the capacity for population recovery in response to good management procedures (Cabral et al., 2001; Kamer et al., 2001; Cardoso et al., 2002, 2004a,b; Lopes et al., 2002; Marques et al., 2002; Múrias et al., 2002; Dolbeth et al., 2003). The hypotheses to be tested include: (1) that the selected levels are representative of the estuarine trophic chain that changes in some predictable way with increases of anthropogenic influence and (2) that the relevant ecological drifts observed can be represented by the state variables, assumed as important key-components, used in the dynamic model construction. These hypotheses were tested by new applications of the SDM in order to capture, in a holistic perspective, the complexity of some ecological processes resulting from the gradients of the ongoing environmental changes in the studied estuarine ecosystem.

\section{Materials and methods}

\subsection{Study area}

The Mondego estuary $\left(40^{\circ} 08^{\prime} \mathrm{N}, 8^{\circ} 50^{\prime} \mathrm{W}\right)$ is located in a warm temperate region with a basic Mediterranean temperate climate. The estuary is $7 \mathrm{~km}$ long and 2-3 km wide, covers an area of 1072 ha and consists of two different arms, north and south, separated by an alluvium-formed island (Murraceira island) (Fig. 1). Two main different types of communities were identified in the south arm mudflats (Marques et al., 2002; Dolbeth et al., 2003): (1) Z. noltii meadows in downstream areas where the nutrient concentration is lower (Fig. 1, area A). These meadows have a diversified macroinvertebrate assemblage where Hydrobia ulvae represent about $75 \%$ of the total yearly production (Dolbeth et al., 2003); (2) an Enteromorpha dominant community, with the main presence of Cyathura carinata populations, is found in the upstream areas with lower salinity values and higher nutrient concentration in water (Fig. 1, area C). A third area was considered as an intermediate situation (Fig. 1, area B), in terms of nutrient enrichment, to complete the spatial gradient of eutrophication in the Mondego estuary (Dolbeth et al., 2003; Pardal et al., 2004). Sampling occurred in these three areas of the south arm (Fig. 1), where water circulation is dependent on tidal activity and on small freshwater input from a tributary, the Pranto river, which is artificially controlled by a sluice and regulated according to the water needs in rice fields from the Pranto valley (Flindt et al., 1997; Pardal et al., 2000; Dolbeth et al., 2003). The freshwater discharge proceeding from the Pranto into the south arm represents an important inorganic nutrient input to the system (Flindt et al., 1997) due to fertilizers used in the rice crops (Anastácio et al., 1999; Lillebø et al., 1999a; Pardal et al., 2000). Although a large part of the southern arm intertidal area still remains more or less unchanged, macroalgae blooms have been regularly observed over the last 2 decades (Pardal et al., 2000; Dolbeth et al., 2003). This is probably a result of excessive nutrient release into the estuary, coupled with longer persistence of inorganic nutrients in the water column (Flindt et al., 1997; Martins et al., 2001).

\subsection{Field programme}

Physicochemical factors of water and sediments, macrophytes, macroalgae and benthic macroinvertebrates were monitored in three different periods: (a) every 2 weeks from January 1993 to December 1994 and then monthly until September 1995 at the three study areas of the south arm of the estuary (A-C, Fig. 1), (b) monthly from January 1996 to January 1997 and (c) from February 1999 to April 2000 only in areas A and C (Pardal et al., 2000; Martins et al., 2001). The counts of feeding wading birds were carried out fortnightly from October 1993 to October 1994 (Cabral et al., 1999) and monthly from January 1996 to January 1997 and from February 1999 to April 2000 along the entire south arm (Lopes et al., 2002).

\subsection{Data analysis}

The SDM model proposed is preceded by a conventional multivariate statistical procedure. A stepwise multiple regression analysis (Zar, 1996) was used to test for relationships between dependent and independent variables. The dependent variables, 


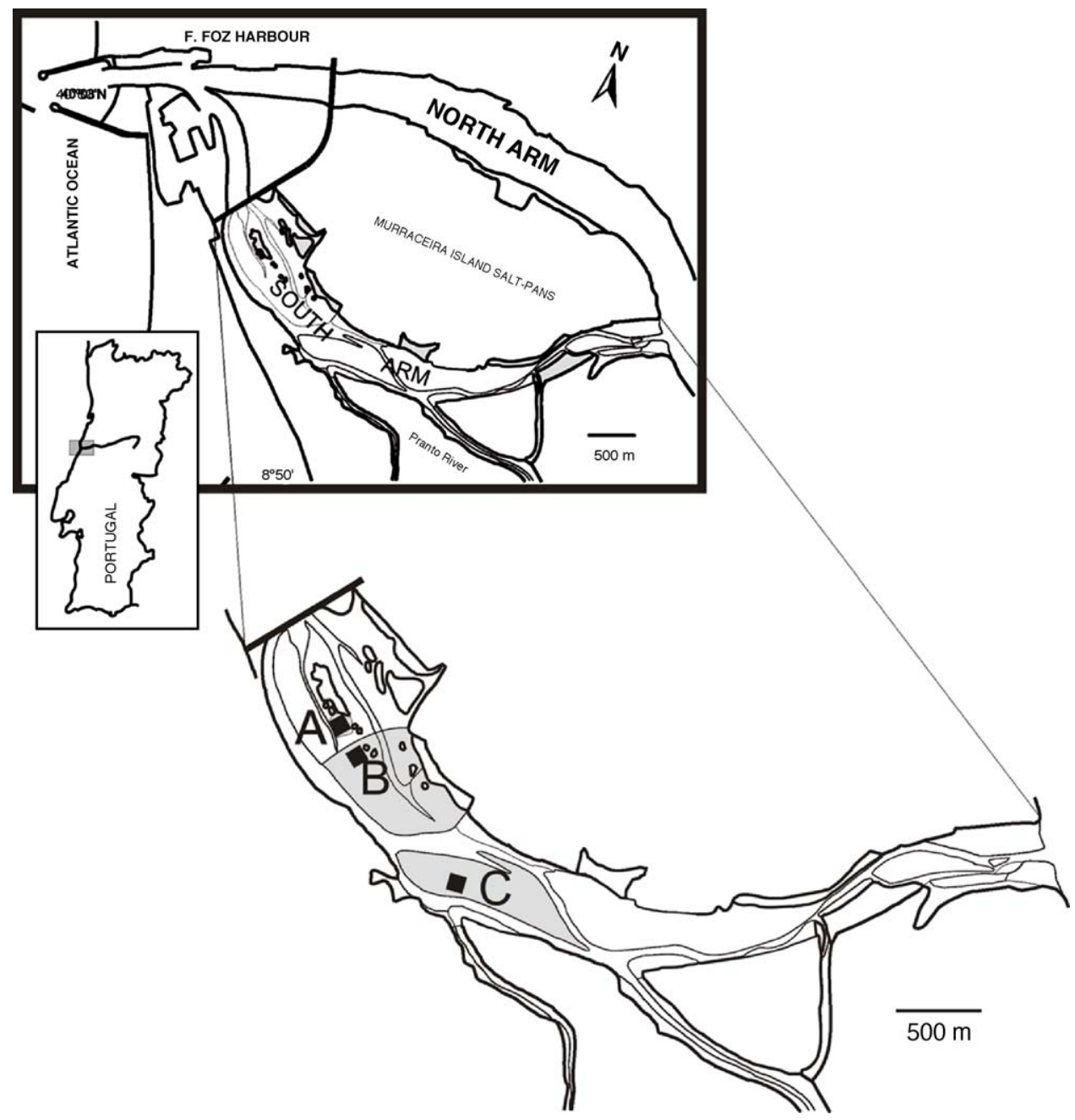

Fig. 1. Location of the sampling areas in the south arm of the Mondego estuary: (A) Zostera noltii meadows, (B) intermediate area and (C) most eutrophic area.

selected as representative of the estuarine trophic chain, were: (a) the total biomass of the green macroalgae (resulting from the sum of Enteromorpha spp. and Ulva spp. biomass), (b) the biomass of $Z$. noltii, (c) the biomass of two key-species of the macroinvertebrate community $(H$. ulvae and $C$. carinata) and (d) the number of species and number of individuals of waders. From a bottom up perspective, each living component interacting with other living components (e.g., competition and predation interactions) and non-living features of their shared habitat. Therefore, a step down procedure was used so that the effect of each variable in the presence of all other pertinent variables could be examined first with the least significant variable being removed at every step. The analysis stopped when all the remaining variables had a significant level $P<0.05$ (Zar, 1996). Despite the limitations inherent to a academic demonstration, this procedure gives realism to the trophic interactions considered by incorporating into the model a typical "cascade effect" observed in the dynamic of these communities (Dolbeth et al., 2003). In fact, nutrient-stimulated macroalgal mats may determine severe effects on macrophyte-dominated systems, the success of predaceous macroinvertebrate feeding on infaunal 
communities, the efficiency of shorebirds seeking prey on marsh mudflats, and many others upwardly cascading effects (Cabral et al., 1999; Valiela et al., 2004). Therefore, in order to simplify the model structure, only the main trophic key-components were introduced as representative ecological indicators, but which obviously could be complemented by other relevant state variables or other dynamic variables in further applications. The specifications of all variables considered are indicated in Table 1. Although the lack of normal distribution of the dependent variables was not solved by any transformation (Kolmogorov-

Table 1

Specification of all variables considered in this study (IN and OUT represent, respectively, the surviving independent variables (used in the dynamic model construction) and the removed independent variables by a previous step down multiple regression analysis.)

\begin{tabular}{|c|c|c|}
\hline Variables & Specification & Code \\
\hline \multicolumn{3}{|l|}{ Independent variables IN } \\
\hline Ammonia-N & $\mathrm{mg} \mathrm{L}^{-1} \mathrm{NH}_{4}^{+}$ & $\mathrm{NH}_{4}$ \\
\hline $\begin{array}{l}\text { Medium substrate } \\
\text { grain size }\end{array}$ & $\mathrm{mm}$ & MSUB \\
\hline Organic matter & $\%$ & $\mathrm{OM}$ \\
\hline Dissolved oxygen & $\mathrm{mg} \mathrm{L}^{-1}$ & $\mathrm{O}_{2}$ \\
\hline $\mathrm{pH}$ & $\mathrm{pH}$ units & $\mathrm{pH}$ \\
\hline Photoperiod & $\min$ & PHOTPER \\
\hline Salinity & $\mathrm{g} \mathrm{L}^{-1}$ & SALIN \\
\hline Silica & $\mathrm{mg} \mathrm{L}^{-1} \mathrm{Si}$ & SILIC \\
\hline Water residence time & $\mathrm{h}$ & TIMERES \\
\hline \multicolumn{3}{|l|}{ Independent variables OUT } \\
\hline $\begin{array}{l}\text { Area covered by } \\
\text { algal mats }\end{array}$ & $\%$ & $\mathrm{AC}$ \\
\hline Nitrates & $\mathrm{mg} \mathrm{L}^{-1} \mathrm{~N}$ & NTA \\
\hline Nitrites & $\mathrm{mg} \mathrm{L}^{-1} \mathrm{~N}$ & NTI \\
\hline $\mathrm{N} / \mathrm{P}$ ratio & & NP \\
\hline Phosphorous & $\mathrm{mg} \mathrm{L}^{-1} \mathrm{P}$ & $\mathrm{P}$ \\
\hline Accumulated precipitation & $\mathrm{mm}$ & AP \\
\hline Water temperature & ${ }^{\circ} \mathrm{C}$ & TEMP \\
\hline \multicolumn{3}{|l|}{ Dependent variables } \\
\hline $\begin{array}{l}\text { Biomass of Cyathura } \\
\text { carinata }\end{array}$ & $\mathrm{g} \mathrm{m}^{-2}$ AFDW & CYAT \\
\hline $\begin{array}{l}\text { Biomass of } \\
\text { Hydrobia ulvae }\end{array}$ & $\mathrm{g} \mathrm{m}^{-2}$ AFDW & HYD \\
\hline $\begin{array}{l}\text { Biomass of } \\
\text { Enteromorpha spp. }\end{array}$ & $\mathrm{g} \mathrm{m}^{-2}$ AFDW & ENT \\
\hline Biomass of Ulva sp. & $\mathrm{g} \mathrm{m}^{-2}$ AFDW & ULV \\
\hline $\begin{array}{l}\text { Biomass of } \\
\text { Zostera noltii }\end{array}$ & $\mathrm{g} \mathrm{m}^{-2}$ AFDW & ZOST \\
\hline Total number of birds & $\begin{array}{l}\text { Number of } \\
\text { individuals }\end{array}$ & TBIRD \\
\hline Number of birds species & Number of species & SPBIRD \\
\hline
\end{tabular}

Smirnov test), the linearity and the homocedasticity of the residuals were achieved by using logarithmic transformations $\left(X^{\prime}=\log _{10}[X+1]\right)$ in each side of the equation, i.e., on both the dependent and independent variables (Zar, 1996). The lack of substantial intercorrelation among independent variables was respected by the inspection of the respective tolerance values. All the statistical analysis was carried out using the software SYSTAT $8.0^{\circledR}$. Since the previous statistical procedure were based on data sets that include true gradients of environmental and biological characteristics, over space and time, the significant partial regression coefficients were assumed as relevant holistic ecological parameters in the dynamic model construction. This is the heart of the philosophy of the SDM. In a holistic perspective, the partial regression coefficients represent the global influence of the environmental and trophic variables selected, which are of significant importance on several complex ecological processes. Yet, the latter were not included explicitly in the model, but were related to the state variables under consideration. Such procedure was based on data from January 1993 to September 1995 at the three study areas (Fig. 1), excepting wading birds counts carried out from October 1993 to October 1994 along the entire south arm. To develop the dynamic model we used STELLA $5.0^{\circledR}$.

For validation purposes, biological and physicochemical data, from two independent periods (January 1996-January 1997 and February 1999-April 2000), were used to confront the simulated values of a given state variable with the real values of the same component. A regression analysis (MODEL II) was performed to compare the observed real values of the selected trophic components with the expected values obtained by model simulations for the same periods. At the end of each analysis, the $95 \%$ confidence limits for the intercept and the slope of the regression line were determined which, together with the results of the respective analysis of variance (ANOVA), allowed to assess the proximity of the simulations produced with the observed values (Sokal and Rohlf, 1995). When the results of the regression analysis were statistically significant, i.e., when the intercept of the regression line was not statistically different from 0 and the slope was not statistically different from 1, the model simulations were considered validated (Sokal 
and Rohlf, 1995; Oberdorf et al., 2001). When the validation procedure was not possible (e.g., observations with non-variable values, such as the value $0 \mathrm{~g} \mathrm{~m}^{-2}$ of $Z$. noltii biomass in area $\mathrm{C}$, the percentage of coincidence between simulated and observed points was calculated.

\section{Results and discussion}

\subsection{Effects of environmental factors in trophic levels}

A stepwise multiple-regression analysis was used to search for significant correlations between biological and environmental variables of the three areas used in the model construction. The first trophic level (primary producers) was affected by several physicochemical parameters (Table 2). Significant negative correlations were also detected between $Z$. noltii (ZOST) and Enteromorpha spp. (ENT) biomass, which revealed either different spatial habitat occurrences or some degree of competition between these two autotrophic components. For the second trophic level, the physicochemical and primary producers' biomass variables seemed to be the main influencing factors on H. ulvae (HYD) and C. carinata (CYAT) biomass tendencies (Table 2). From the upper trophic level, the number of wading bird species (SPBIRD) was influenced by the preceding level (concretely by C. carinata biomass), by the substrate grain size and photoperiod (Table 2). With regard to the total number of birds (TBIRD), this measure was significantly correlated only with photoperiod (Table 2), an independent variable not related directly with the environmental changes studied. All the biological and physicochemical significant influences are expressed in Table 2.

\subsection{Conceptualization of the model and equations}

The diagram of the model presented in Fig. 2 is based on the relationships detected in multiple regression analysis (Table 2) and on existing relevant regional data sets. Therefore, the model includes the following seven state variables: three related to the primary producers biomass, two related to the macroinvertebrate biomass and two related to the wading bird number of individuals and species, respectively (Fig. 2). Since difference equations that describe the processes affecting the state variables are expressed in a logarithm of the biological variables (Table 3, difference equations), the initial values of all state variables, indicated in Table 3 (process equations), are expressed in a logarithm of the respective

Table 2

The regression equations, degrees of freedom (d.f.), coefficient of determination $\left(R^{2}\right), F$-values and their significance level for all the variables combination selected as significant by stepwise multiple regression

\begin{tabular}{|c|c|c|c|}
\hline Equations & d.f. & $R^{2}$ & $F$-value \\
\hline $\begin{array}{l}\log \text { ENT }=-14.781+4.567(\log \text { PHOTPER })+1.394\left(\log \mathrm{O}_{2}\right)+ \\
1.441(\log \mathrm{OM})-0.354(\log \text { ZOST })\end{array}$ & 141 & 0.446 & $28.34^{* * * *}$ \\
\hline $\begin{array}{l}\log \text { ULV }=-4.470+0.544(\log \text { SALIN })+ \\
\quad 4.030(\log p H)-0.079(\log \text { ZOST })\end{array}$ & 142 & 0.164 & $9.299^{* * * *}$ \\
\hline $\begin{array}{l}\log \mathrm{ZOST}=-1.677+2.493(\log \text { PHOTPER })- \\
3.160(\log \text { TIMERES })-3.902\left(\log \mathrm{NH}_{4}\right)+ \\
1.593(\log \mathrm{OM})-0.948(\log \text { ENT })+0.552(\log \mathrm{ULV})\end{array}$ & 139 & 0.531 & $26.249^{* * * *}$ \\
\hline $\begin{array}{l}\log \text { CYAT }=-0.949-0.760(\log \text { PHOTPER }) \\
\quad+2.385(\log \text { TIMERES })+0.569(\log \text { SILIC })- \\
0.570(\log \text { OM })+0.140(\log \text { ENT })+0.055(\log \text { ZOST })\end{array}$ & 139 & 0.748 & $68.918^{* * *}$ \\
\hline $\begin{array}{c}\log \text { HYD }=0.306+0.859(\log \text { SILIC })+1.059\left(\log \mathrm{NH}_{4}\right)+ \\
0.313(\log \text { ULV })+0.529(\log \text { ZOST })\end{array}$ & 141 & 0.782 & $126.213^{* * * *}$ \\
\hline $\begin{array}{r}\log \text { SPBIRD }=3.321-3.442(\log \text { MSUB })+ \\
0.206(\log \text { CYAT })-0.794(\log \text { PHOTPER })\end{array}$ & 44 & 0.385 & $9.163^{* * * *}$ \\
\hline $\log$ TBIRD $=20.237-6.098(\log$ PHOTPER $)$ & 46 & 0.583 & $64.379^{* * *}$ \\
\hline
\end{tabular}

The specification of all variable codes is expressed in Table 1.

**** $P<0.001$ 
Table 3

Mathematical equations used in STELLA for the trophic relationships between the biological and the environmental variables

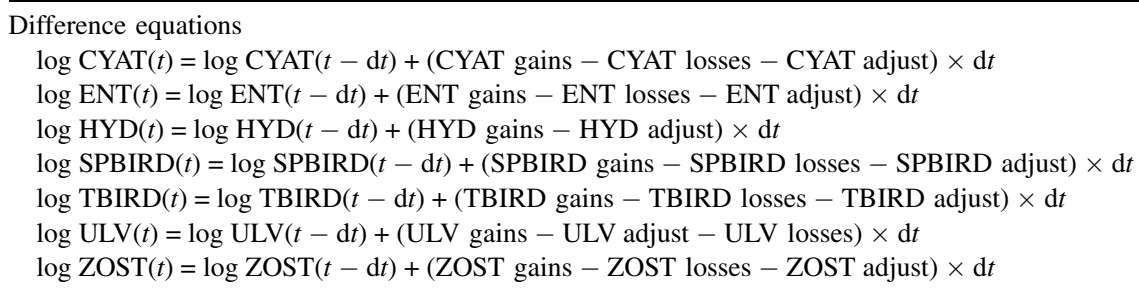

Process equations

(a) $\log$ CYAT

Initial biomass of $\log$ CYAT $=0.9841$

CYAT gains $=2.385 \times \log$ TIMERES $+0.569 \times \log$ SILIC $+0.140 \times \log$ ENT $+0.055 \times \log$ ZOST

CYAT losses $=0.949+0.760 \times \log$ PHOTPER $+0.570 \times \log$ OM

CYAT adjust $=\log$ CYAT

(b) $\log$ ENT

Initial biomass of $\log \mathrm{ENT}=0$

ENT gains $=4.567 \times \log$ PHOTPER $+1.394 \times \log \mathrm{O}_{2}+1.441 \times \log \mathrm{OM}$

ENT losses $=14.781+0.354 \times \log$ ZOST

ENT adjust $=\log$ ENT

(c) $\log$ HYD

Initial biomass of $\log \mathrm{HYD}=0.3549$

HYD gains $=0.306+0.859 \times \log$ SILIC $+1.059 \times \log \mathrm{NH} 4+0.313 \times \log \mathrm{ULV}+0.529 \times \log \mathrm{ZOST}$

HYD adjust $=\log$ HYD

(d) $\log$ SPBIRD

Initial biomass of $\log$ SPBIRD $=1.2304$

SPBIRD gains $=3.321+0.206 \times \log$ CYAT

SPBIRD losses $=3.442 \times \log$ MSUB $+0.794 \times \log$ PHOTPER

SPBIRD adjust $=\log$ SPBIRD

(e) $\log$ TBIRD

Initial biomass of $\log$ TBIRD $=3.3397$

TBIRD gains $=20.237$

TBIRD losses $=6.098 \times \log$ PHOTPER

TBIRD adjust $=\log$ TBIRD

(f) $\log \mathrm{ULV}$

Initial biomass of $\log \mathrm{ULV}=0$

$\mathrm{ULV}$ gains $=0.544 \times \log \mathrm{SALIN}+4.030 \times \log \mathrm{pH}$

ULV losses $=4.470+0.079 \times \log$ ZOST

$\mathrm{ULV}$ adjust $=\log$ ULV

(g) $\log$ ZOST

Initial biomass of $\log \mathrm{ZOST}=0$

ZOST gains $=2.493 \times \log$ PHOTPER $+1.593 \times \log$ OM $+0.552 \times \log \mathrm{ULV}$

ZOST losses $=1.677+3.160 \times \log$ TIMERES $+3.902 \times \log \mathrm{NH}_{4}+0.948 \times \log$ ENT

ZOST adjust $=\log$ ZOST

Associated variables

CYAT $=($ antilog CYAT $)-1$

$\mathrm{ENT}=($ antilog ENT $)-1$

$\mathrm{HYD}=(\operatorname{antilog} \mathrm{HYD})-1$ 
Table 3 (Continued)

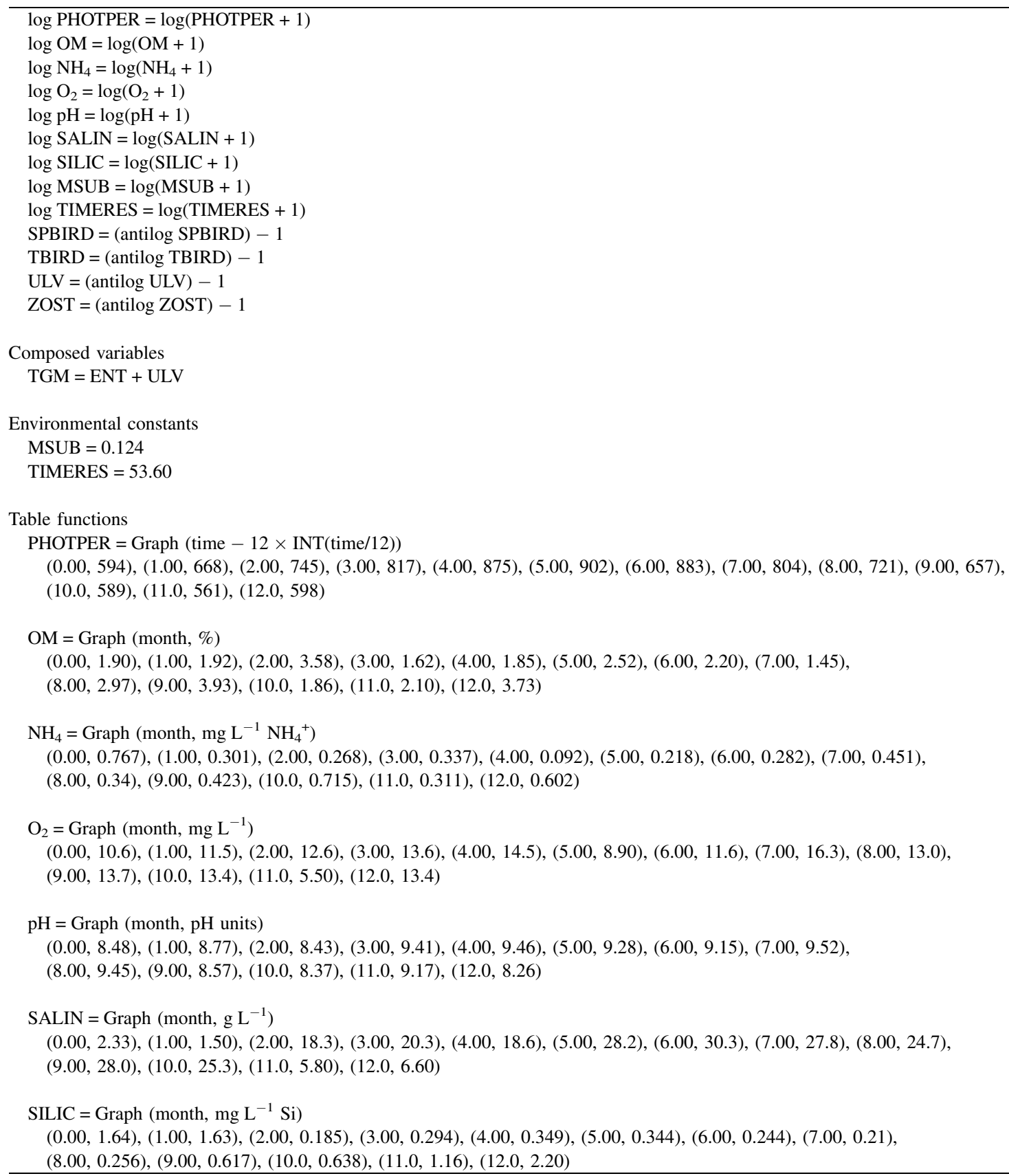

As an example, the environmental data of the sampling area C (from January 1996 to January 1997) was used. The specification of all variable codes is expressed in Table 1 . 


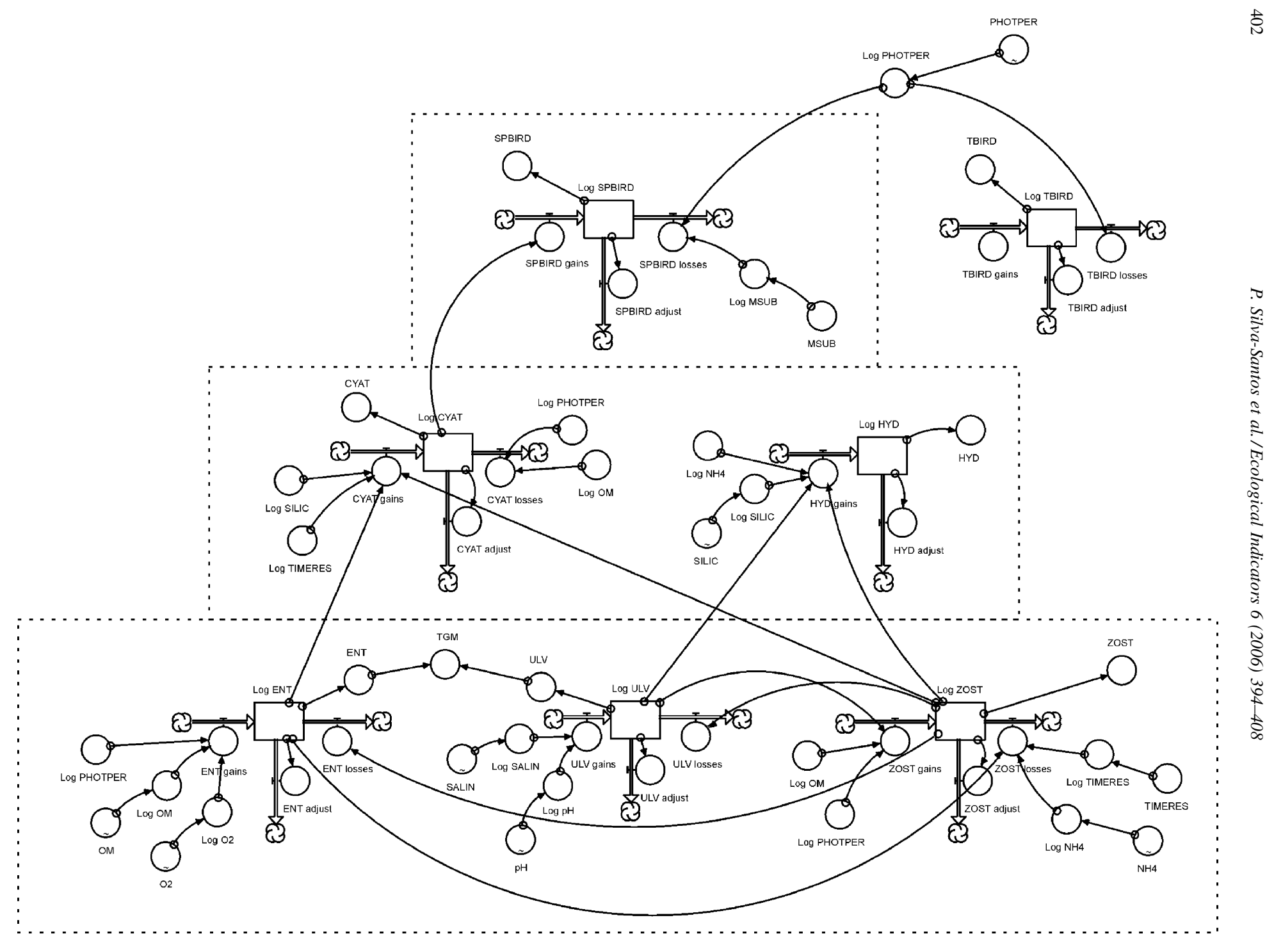

Fig. 2. Conceptual diagram of the model used to predict the trophic drifts produced by gradients of changes of the environmental variables from the studied areas in the south arm of the Mondego estuary. The pyramidal boxes represent the trophic "cascade effect". The specification of all variable codes is expressed in Table 1. 
units. Later, for validation purposes, the initial value (January 1996 and February 1999) was discarded, since only in $t_{1}$ (first point of the simulation) it was possible to take into account the influences of the environmental variables, whose seasonal fluctuations were introduced into the model as table functions (Table 3, table functions). The inflows affecting the ecological state variables, Enteromorpha (ENT gains), Ulva (ULV gains), Zostera (ZOST gains), Hydrobia (HYD gains), Cyathura (CYAT gains), number of bird species (SPBIRD gains) and total number of birds (TBIRD gains) were based on the positive constants and all positive partial coefficients of each variable resulting from the previous multiple regression analysis (Fig. 2; Tables 2 and 3, difference and process equations). On the other hand, with exception of Hydrobia biomass (log HYD), all variables were affected by an outflow (ENT losses, ULV losses, ZOST losses, CYAT losses, SPBIRD losses and TBIRD losses) related to the negative constants and partial regression coefficients (Fig. 2; Tables 2 and 3, difference and process equations). Although biomass output for each metric in our SDM model simulation is composed of a given value per time unit, the respective state variable might have a cumulating behaviour over time in response to environmental condition changes. Therefore, to prevent this from happening, seven outflow adjustments were incorporated in the model (ENT adjust, ULV adjust, ZOST adjust, HYD adjust, CYAT adjust, SPBIRD adjust and TBIRD adjust). These outflow adjustments aim to empty the state variables at each time step, by a "flushing cistern mechanism", before beginning the next step with new environmental influences (Fig. 2; Table 3, difference and process equations). For process compatibilities and a more realistic comprehension of the model simulations, some conversions were introduced, denominated associated variables (Fig. 2; Table 3, associated variables). Regarding biological variables, these conversions were obtained through an inverse transformation (anti-logarithmic), which transforms logarithms into the original measurement units (ENT, ULV, ZOST, HYD, CYAT, SPBIRD and TBIRD). The physicochemical variables were logarithm transformed for a compatible integration in the balances of the state variables (Fig. 2; Table 3, associated variables). This transformation was incorporated because the data required for the state variables balances should have the same units used to obtain the partial regression coefficients, assumed as holistic ecological parameters (see Section 2). Therefore, only logarithms of the physicochemical variables are acceptable in the inflows and outflows of the state variables (Fig. 2; Tables 2 and 3, difference and process equations). Thus, the model is prepared for receiving and transforming real data from the environmental variables and to convert logarithmic outputs from state variables simulations into original units. Total green macroalgae biomass (TGM), resulting from the sum of the associated variables ENT and ULV, was used to complete the output of the model and named composed variable (Table 3, composed variables). Some environmental values, such as medium substrate grain size (MSUB) and water residence time (TIMERES-time needed to renovate $90 \%$ of a certain initial volume of water) in each sampling area were assumed as static (Duarte et al., 2001), without any variation during the simulated period, and therefore, were introduced as environmental constants (Table 3, environmental constants).

\subsection{Model simulations}

The temporal unit chosen was the month because it captures in an acceptable way the average ecological variations that occur in the Mondego estuary. The simulations performed were divided in two periods: from January 1996 to January 1997 and from February 1999 to April 2000. Since the values of the first month for each period were used as initial values $\left(t_{0}\right)$, the simulations started effectively in February 1996 and March 1999.

The Fig. 3 illustrates the confrontation between simulated and the real values for all the biological variables under consideration. The available observed data from the sampling campaigns carried out in the last years allowed us to compare values for primary producers in areas $\mathrm{A}$ and $\mathrm{C}$, for benthic macroinvertebrates only in area $\mathrm{C}$ and for wading birds in the south arm as a whole. For three of the eight simulations performed, the model predicts with success the behaviour of the total green macroalgae biomass in area $\mathrm{A}$, the number of bird species (SPBIRD) and the total number of birds (TBIRD) in the entire south arm (Fig. 3), which were statistically validated by the 

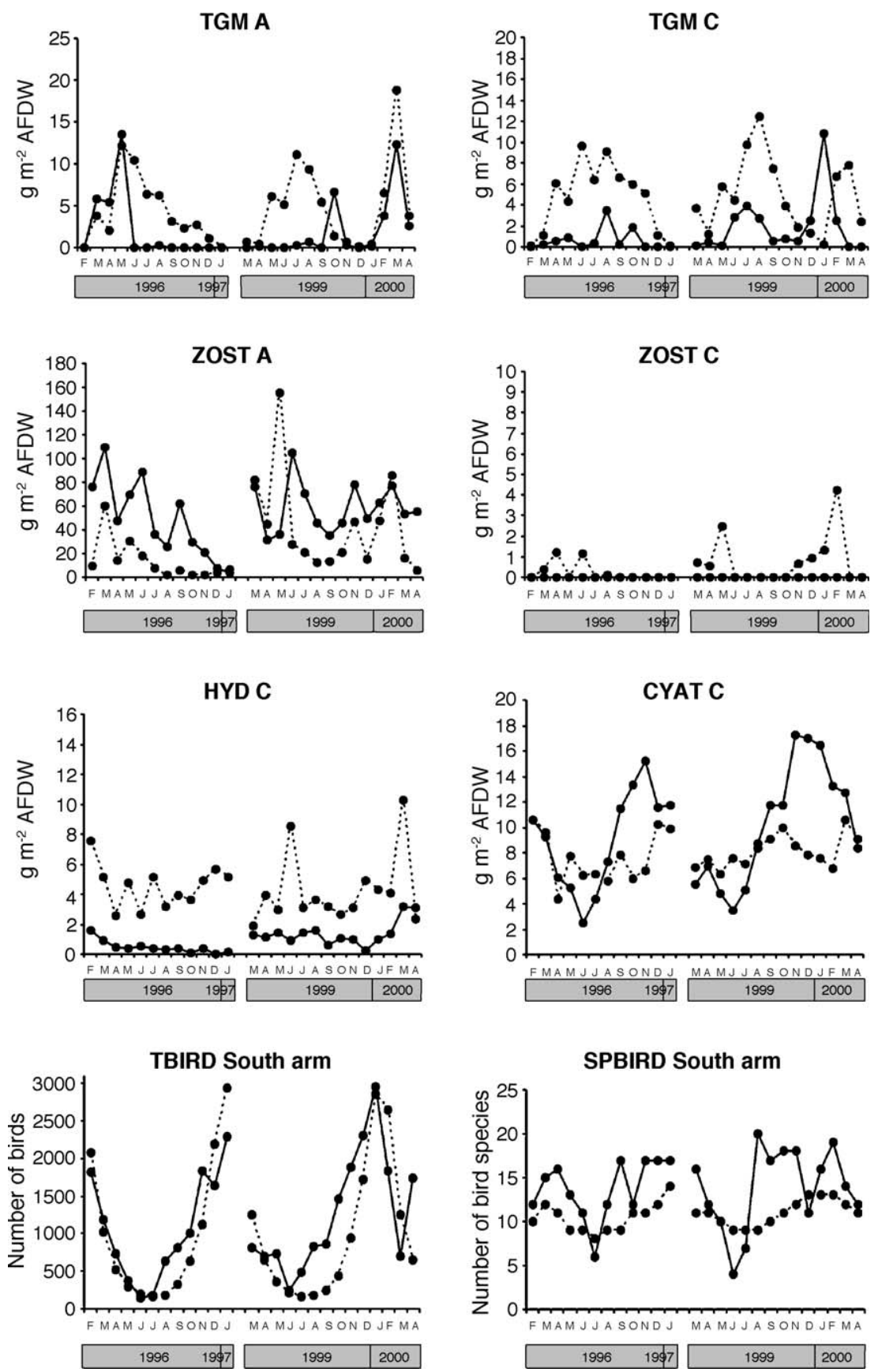

Fig. 3. Graphical comparisons between simulated (dashed line) and observed (solid line) values of the following biological variables: total green macroalgae biomass (TGM), Zostera noltii biomass (ZOST), Hydrobia ulvae biomass (HYD), Cyathura carinata biomass (CYAT), total number of birds (TBIRD) and number of bird species (SPBIRD). A and $\mathrm{C}$ are the two sampling areas, from which the available data is used for validation purposes. 
Table 4

Regression analysis (MODEL II) results: intercepts, slopes and respective 95\% confidence limits (in parenthesis), degrees of freedom (d.f.), coefficient of determination $\left(R^{2}\right)$ and $F$-values and their significance level for all the observed vs. expected values of the biological variables considered

\begin{tabular}{|c|c|c|c|c|c|c|}
\hline Metrics & Station & Intercept & Slope & d.f. & $R^{2}$ & $F$-value \\
\hline TGM & A & $-1.10(-4.49 ; 0.92)$ & $0.67(0.23 ; 1.41)$ & 25 & 0.3034 & $10.453^{* * *}$ \\
\hline TGM & $\mathrm{C}$ & $1.30(-1.56 ; 4.12)$ & $0.01(-0.58 ; 0.61)$ & 25 & 0.0001 & 0.002 (n.s.) \\
\hline ZOST & $\mathrm{A}$ & $40.74(9.75 ; 58.02)$ & $0.45(-0.15 ; 1.51)$ & 25 & 0.0784 & 2.042 (n.s.) \\
\hline HYD & $\mathrm{C}$ & $0.50(-0.40 ; 1.37)$ & $0.10(-0.10 ; 0.31)$ & 25 & 0.0454 & 1.141 (n.s.) \\
\hline CYAT & $\mathrm{C}$ & $-40.73(-13.95 ; 676.41)$ & $6.43(-85.07 ; 3.01)$ & 25 & 0.1303 & 3.596 (n.s.) \\
\hline TBIRD & Entire south arm & $390.72(128.78 ; 598.13)$ & $0.79(0.58 ; 1.06)$ & 25 & 0.6668 & $48.038^{* * * * *}$ \\
\hline SPBIRD & Entire south arm & $-36.89(-185.63 ;-14.41)$ & $4.72(2.63 ; 18.59)$ & 25 & 0.2345 & $7.351^{*}$ \\
\hline
\end{tabular}

n.s., not significant. The specification of all variable codes is expressed in Table 1 .

${ }^{*} P<0.05$.

** $P<0.01$.

*** $P<0.001$.

MODEL II regression analysis (Table 4). The photoperiod was the only single factor with significant influence on TBIRD. Nevertheless, this simplistic cause-effect relationship produces very good estimations of the total number of birds that use the south arm through the studied periods. Although photoperiod is a well-known factor that determines wader migrations, the respective variation is obviously indifferent to the ongoing local environmental changes in the studied mudflats. The resultant independent "steady state" may be explained by the observations of Múrias et al. (1996) suggesting that the presence of algae over the sediments did not strongly influence the abundance of the feeding waders in the south arm of the Mondego estuary. With regard to C. carinata biomass (CYAT), the performance of the model in predicting the respective tendencies in area $\mathrm{C}$ is almost significant $(P=0.07$, Table 4$)$, with a seasonal stable pattern (Fig. 3) that is consistent with the population trends from the south of Europe (Bamber, 1985; Sola and Arzubialde, 1993; Marques et al., 1994; Pardal et al., 2002). Despite the non-significant results for the remaining variables, we could easily recognize logical behavioural patterns, although sometimes underestimated or overestimated, in the simulations for Z. noltii biomass (ZOST) in area A and total green macroalgae biomass in area C (Fig. 3; Table 4). Since it was not possible to validate the simulations produced for $Z$. noltii biomass (ZOST) in area C, the performance was empirically assessed by the inspection of the degree of coincidence between simulated and observed values. From a total of 26 points (months) simulated, 16 were coincident with real data, which represents $61.5 \%$ of coincidence (Fig. 3). Moreover, the model reacted in a differentiated way between area A, with favourable conditions for $Z$. noltii occurrence in high biomass values, and area $C$, where the conditions needed for the establishment of a community of $Z$. noltii were deficient (Lilleb $\varnothing$ et al., 1999b; Pardal et al., 2000; Martins et al., 2001) (Fig. 3). The worst performance of the model, in terms of both statistical results and behavioural patterns, was obtained for $H$. ulvae biomass estimates, which are systematically overestimated in area C (Fig. 3; Table 4). Although some studies reveal $H$. ulvae as an important prey item in waders' diet (Raffaelli and Milne, 1987; Múrias et al., 2002), others categorised it as a low-quality food item (Aarnio and Matilla, 2000). In our model only $C$. carinata biomass was selected as an influent positive factor on the upper trophic level dynamics, represented by the number of wader species (Fig. 2). These results are in agreement with Lopes et al. (1998), who described C. carinata as an important prey for waders in the Mondego estuary.

The monitoring of the proposed ecological indicators, specially focused in the Z. noltii beds, was included on ecosystem health assessments carried out for the south arm of the Mondego estuary since 1998. In this scope, some mitigation actions were implemented: (1) the water circulation was partially re-established allowing freshwater inputs from the north arm every high tide situations (favouring nutrients dilution and decreasing the water residence time) and (2) the nutrient loadings were reduced by correcting the inappropriate sluice handling and fertilizers overloading (Verdelhos et al., 2005). In 
such programs, the rapid construction of predictive tools for ecological management, namely in terms of cost and speed of reliable assessment results, is crucial. Overall, the model simulations shows that the ecological indicators represented by the state variables are sensitive to the studied environmental changes, capturing the "trophic cascade" dynamics that typically occur in estuarine ecosystems. Therefore, the further improvement of our SDM model will be integrated in the Mondego estuary management program.

\section{Conclusions}

The objective of the holistic methodology proposed is a mechanistic understanding of the trophic dynamics, based on stochastic principles, from which management strategies can be designed to restore coastal ecosystems functions and biological communities that have been damaged by the eutrophication phenomena. Our approach includes any kind of trophic interaction between biological key-components and environmental resources, with holistic and ecological relevance, and reduces the number of preconceptions added to the model. Therefore, this study seems to represent a useful initial contribution to give a consistent mechanistic basis for the holistic assessment of the ecological status within the "data space" of the environmental gradients monitored in changed ecosystems. Another goal when developing methodologies for assessing changes in the ecological integrity of ecosystems is the feasibility of application and extent to which the results can be applied in other areas (Andreasen et al., 2001). In fact, the SDM is expeditious and easily applicable to other type of natural, semi-natural and artificial ecosystems affected by gradients of changes (Santos and Cabral, 2003; Cabecinha et al., 2004).

Overall, the main results showed that, as with any complex process in science, it is valid, interesting, and instructive to construct stochastic dynamic models by focusing on the interactions between key-components of changing natural ecosystems. This approach also provides a useful starting point, allowing the precise development of more complicated models, with introduction of other mechanisms and interactions with precise applicability conditions. The ultimate goal is to produce simulation models that permit the creation of landscape patterns from changes in ecosystems, whose patterns are the basis of spatially explicit ecological models (Costanza and Voinov, 2003). Therefore, we believe that our approach will provide the development of more global techniques in the scope of this research area by creating expeditious interfaces with Geographic Information Systems, which will make the methodology more instructive and credible to decision-makers and environmental managers (Costanza, 1992; Santos and Cabral, 2003).

\section{Acknowledgements}

The authors are indebted to all the colleagues from the University of Coimbra who assisted in field and laboratory work.

\section{References}

Aarnio, K., Matilla, J., 2000. Predation by juvenile Platichthys flesus (L.) on shelled prey species in a bare sand and a drift algae habitat. Hydrobiologia 440, 347-355.

Anastácio, P.M., Frias, A.F., Marques, J.C., 1999. CRISP (crayfish and rice integrated system of production). 1. Modelling rice (Oryza sativa) growth and production. Ecol. Modell. 123, 17-28.

Andreasen, J.K., O’Neill, R.V., Noss, R., Slosser, N.C., 2001. Considerations for the development of a terrestrial index of ecological integrity. Ecol. Indicators 1, 21-35.

Bamber, R.N., 1985. The autoecology of Cyathura carinata (Crustacea: Isopoda) in a cooling water discharge lagoon. J. Mar. Biol. Assoc. U. K. 65, 181-194.

Beukema, J.J., Cadée, G.C., Dekker, R., 2002. Zoobenthic biomass limited by phytoplankton abundance: evidence from parallel changes in two long-term data series in the Wadden Sea. J. Sea Res. 48, 111-125.

Brosse, S., Lek, S., Townsend, C.R., 2001. Abundance, diversity, and structure of freshwater invertebrates and fish communities: an artificial neural network approach. N. Z. J. Mar. Freshwater Res. 35, 135-145.

Cabecinha, E., Cortes, R., Cabral, J.A., 2004. Performance of a stochastic-dynamic modelling methodology for running waters ecological assessment. Ecol. Modell. 175 (3), 303-317.

Cabral, J.A., Pardal, M.A., Lopes, R.J., Múrias, T., Marques, J.C., 1999. The impact of macroalgal blooms on the use of the intertidal area and feeding behaviour of waders (Charadrii) in the Mondego estuary (West Portugal). Acta Oecologica 20 (4), 417-427.

Cabral, J.A., Marques, J.C., Nielsen, S.N., 2001. Modelling mosquitofish (Gambusia holbrooki) responses to genapol OXD-080, a non-ionic surfactant, in rice fields. Ecol. Eng. 16, 537-544. 
Cardoso, P.G., Lillebø, A.I., Pardal, M.A., Ferreira, S.M., Marques, J.C., 2002. The effects of different primary producers on Hydrobia ulvae population dynamics: a case study in a temperate intertidal estuary. J. Exp. Mar. Biol. Ecol. 277 (2), 173-195.

Cardoso, P.G., Pardal, M.A., Raffaelli, D., Baeta, A., Marques, J.C., 2004a. Macroinvertebrate response to different species of macroalgal mats and the role of disturbance history. J. Exp. Mar. Biol. Ecol. 308, 207-220.

Cardoso, P.G., Pardal, M.A., Lillebø, A.I., Ferreira, S.M., Raffaelli, D., Marques, J.C., 2004b. Dynamic changes in seagrass assemblages under eutrophication and implications for recovery. J. Exp. Mar. Biol. Ecol. 302, 233-248.

Chaloupka, M., 2002. Stochastic simulation modelling of southern Great Barrier Reef green turtle population dynamics. Ecol. Modell. 148, 79-109.

Cloern, J.E., 2001. Our evolving conceptual model of coastal eutrophication problem. Mar. Ecol. Prog. Ser. 210, 223-253.

Costanza, R., 1992. Towards an operational definition of ecosystem health. In: Costanza, R., Norton, B., Haskell, B. (Eds.), Ecosystem Health: New Goals for Environmental Management. Island Press, Washington, DC, pp. 239-256.

Costanza, R., Voinov, A., 2003. Introduction: spatially explicit landscape simulation models. In: Costanza, R., Voinov, A. (Eds.), Landscape Simulation Modeling, A Spatially Explicit, Dynamic Approach. Springer Verlag, New York, pp. 320.

Dolbeth, M., Pardal, M.A., Lillebø, A.I., Azeiteiro, U., Marques, J.C., 2003. Short- and long-term effects of eutrophication on the secondary production of an intertidal macrobenthic community. Mar. Biol. 143, 1229-1238.

Duarte, A.S., Pinho, J.L., Pardal, M.A., Neto, J.M., Vieira, J.P., Santos, F.S., 2001. Effect of residence times on River Mondego estuary eutrophication vulnerability. Water Sci. Technol. 44, 329-336.

Flindt, M.R., Kamp-Nielsen, L., Marques, J.C., Pardal, M.A., Bocci, M., Bendoricchio, G., Salomonsen, J., Nielsen, S.N., Jørgensen, S.E., 1997. Description of the three shallow estuaries: Mondego River (Portugal). Roskilde Fjord (Denmark) and the Lagoon of Venice (Italy). Ecol. Modell. 102, 17-31.

Flindt, M.R., Pardal, M.A., Lilleb $\varnothing$, A.I., Martins, I., Marques, J.C., 1999. Nutrient cycling and plant dynamics in estuaries: a brief review. Acta Oecologica 20 (4), 237-248.

Jørgensen, S.E., 1994. Models as instruments for combination of ecological theory and environmental practice. Ecol. Modell. 75/ $76,5-20$.

Jørgensen, S.E., Bernardi, R., 1997. The application of a model with dynamic structure to simulate the effect of mass fish mortality on zooplankton structure in Lago di Annone. Hydrobiologia 356, $87-96$.

Jørgensen, S.E. (Ed.), 2001. Fundamentals of Ecological Modelling. third ed. Elsevier, Amsterdam.

Kamer, K., Boyle, K.A., Fong, P., 2001. Macroalgal bloom dynamics in a highly eutrophic southern California estuary. Estuaries 24 (4), 623-635.

Kareiva, P., Kingsolver, J.G., Huey, R.B., 1993. Biotic interactions and global change. Sinauer Associates, Sunderland, Massachusetts, USA.
Kinney, E.H., Roman, C.T., 1998. Response of primary producers to nutrient enrichment in a shallow estuary. Mar. Ecol. Prog. Ser. 163, 89-98.

Lillebø, A.I., Pardal, M.A., Marques, J.C., 1999a. Population structure, dynamics and production of Hydrobia ulvae (Pennant) (Mollusca: Prosobranchia) along an eutrophication gradient in the Mondego estuary (Portugal). Acta Oecologica 20, 289-304.

Lillebø, A.I., Flindt, M., Pardal, M.A., Marques, J.C., 1999b. The effect of macrofauna, meiofauna and microfauna on the degradation of Spartina maritima detritus from a salt marsh area. Acta Oecologica 20, 249-258.

Lopes, R.J., Cabral, J.A., Múrias, T., Marques, J.C., 1998. Contribution to the study of the diet of the Dunlin Calidris alpina and the Grey Plover Pluvialis squatarola in the Mondego estuary. Airo 9 (1-2), 28-33.

Lopes, R.J., Cabral, J.A., Múrias, T., Pacheco, C., Marques, J.C., 2002. Status and habitat use of waders in the Mondego estuary. In: Pardal, M.A., Marques, J.C., Graça, M.A. (Eds.), Aquatic Ecology of the Mondego River Basin. Global Importance of Local Experience. Imprensa da Universidade de Coimbra, pp. 219-230.

Marques, J.C., Rodrigues, L.B., Nogueira, A.J.A., 1993. Intertidal macrobenthic communities structure in the Mondego estuary (Western Portugal): reference situation. Vie Milieu 43 (2-3), 177-187.

Marques, J.C., Martins, I., Teles-Ferreira, C., Cruz, S., 1994. Population dynamics, life history and production of Cyathura carinata (Krøyer) (Isopoda: Anthuridae) in the Mondego estuary, Portugal. J. Crustacean Biol. 14 (2), 258-272.

Marques, J.C., Pardal, M.A., Maranhão, P., 2002. Characterisation of the macroinvertebrate benthic communities in the Mondego estuary. In: Pardal, M.A., Marques, J.C., Graça, M.A. (Eds.), Aquatic Ecology of the Mondego River Basin. Global Importance of Local Experience. Imprensa da Universidade de Coimbra, pp. 169-197.

Martins, I., Pardal, M.A., Lillebø, A.I., Flindt, M.R., Marques, J.C., 2001. Hydrodinamics as a major factor controlling the occurrence of green macroalgal blooms in a eutrophic estuary: a case study on the influence of precipitation and river management. Estuarine Coastal Shelf Sci. 52, 165-177.

Múrias, T., Cabral, J.A., Marques, J.C., Goss-Custard, J.D., 1996. Short-term effects of intertidal macroalgal blooms on the macrohabitat selection and feeding behaviour of wading birds in the Mondego estuary (West Portugal). Estuarine Coastal Shelf Sci. 43, 677-688.

Múrias, T., Cabral, J.A., Lopes, I., Marques, J.C., 2002. Effects of eutrophication on waders (Aves: Charadrii) in the Mondego estuary: a multi-level approach. In: Pardal, M.A., Marques, J.C., Graça, M.A. (Eds.), Aquatic Ecology of the Mondego River Basin. Global Importance of Local Experience. Imprensa da Universidade de Coimbra, pp. 527-540.

Oberdorf, T., Pont, D., Hugheny, B., Chessel, D., 2001. A probabilistic model characterizing fish assemblages of French rivers: a framework for environmental assessment. Freshwater Biol. 46, 399-415.

Pardal, M.A., 1998. Impacto da eutrofização nas comunidades macrobentónicas do Braço Sul do Estuário do Mondego (Portugal). Ph.D. Thesis. University of Coimbra. 
Pardal, M.A., Marques, J.C., Metelo, I., Lillebø, A.I., Flindt, M.R., 2000. Impact of eutrophication on the life cycle, population dynamics and production of Ampithoe valida (Amphipoda) along an estuarine spatial gradient (Mondego estuary, Portugal). Mar. Ecol. Prog. Ser. 196, 207-219.

Pardal, M.A., Marques, J.C., Ferreira, S., Martins, I., Lillebø, A.I., 2002. Life cycle, biology and production of an estuarine Isopod (Cyathura carinata). In: Pardal, M.A., Marques, J.C., Graça, M.A. (Eds.), Aquatic Ecology of the Mondego River Basin. Global Importance of Local Experience. Imprensa da Universidade de Coimbra, pp. 417-434.

Pardal, M.A., Cardoso, P.G., Sousa, J.P., Marques, J.C., Raffaelli, D., 2004. Assessing environmental quality: a novel approach. Mar. Ecol. Prog. Ser. 267, 1-8.

Raffaelli, D., Milne, H., 1987. An experimental investigation of the effects of shorebirds and flatfish predation on estuarine invertebrates. Estuarine Coastal Shelf Sci. 24, 1-13.

Rosenberg, G., Ramus, J., 1984. Uptake of inorganic nitrogen and seaweed surface area:volume ratios. Aquat. Bot. 19 (1-2), $65-72$.

Santos, M., Cabral, J.A., 2003. Development of a stochastic dynamic model for ecological indicators' prediction in changed Medi- terranean agroecosystems of north-eastern Portugal. Ecol. Indicators 3, 285-303.

Sokal, R.R., Rohlf, F.J. (Eds.), 1995. Biometry. third ed. W.H. Freeman and Company, New York.

Sola, J.C., Arzubialde, M., 1993. Dinámica de poblaciones y biología de Cyathura carinata en el estuario del Bidasoa. Publicaciones Especiales del Instituto Español de Oceanografia 11, 57-64.

Terrados, J., Duarte, C.M., Kamp-Nielsen, L., Agawin, N.S.R., Gacia, E., Lacap, D., Fortes, M.D., Borum, J., Lubanski, M., Greve, T., 1999. Are seagrass growth and survival constrained by the reducing conditions of the sediment? Aquat. Bot. 52, 19-34.

Valiela, I., Rutecki, D., Fox, S., 2004. Salt marshes: biological controls of food webs in a diminishing environment. J. Exp. Mar. Biol. Ecol. 300, 131-159.

Verdelhos, T., Neto, J.M., Marques, J.C., Pardal, M.A., 2005. The effect of eutrophication abatement on the bivalve Scrobicularia plana. Estuarine, Coastal Shelf Sci. 63, 261-268.

Voinov, A., Voinov, H., Costanza, R., 2001. Surface water flow in landscape models. 2. Patuxent watershed case study. Ecol. Modell. 119, 211-230.

Zar, J.H., 1996. Biostatistical Analysis, third ed. Prentice-Hall International Inc., Englewood Cliffs, New Jersey. 